DOI : $10.14746 /$ ps.2019.1.27

\title{
Russian Scientific Journals in the Area of International Relations -2018 Review
}

The paper constitutes a review of articles published in 2018 on the pages of Russian academic journals dealing with international relations. The author has selected texts from issues of: "Russia in Global Affairs," "International Trends. Journal of International Relations Theory and World Policy", "Polis. Political Studies", "Comparative Politics. Russia" and "International Affairs (Russian version)." The presented articles have been analyzed in the context of thematic groups.

The main theme, exciting absolute majority of Russian authors in the field of international relations and international politics, is the theme of the imperfections of the modern system of international relations and politics, particularly in closest relation to the Russian Federation and the inevitability of its changes. For example, the article «Fast current moment» begins with the author's introduction that "the deformations and stresses in the global international system of relation has been accumulating and simmering for many years, and now all these things is spilled out. The nature of the changes in the modern just world be realize - it is difficult to get rid of the inertia of thinking after the Cold War and the temptation to find a parallel in history" (Tsigankov, Trenin, Lomanov, etc., 2018: 14-22). In some aspects, is very evident the fundamental contradiction between the "Russian" and "US-European" view of the modern international relations system. For example, in the article „Russia in XXI century: hopes and achievements" the author notes that "the word of revision is the revision of the existing state of affairs, including, perhaps, in relation to the modern world. What, in fact, is Russia striving for, wishing to pursue a more independent political and economic course" (Lukin, Oznobischev, 2018: 180-188). This contradiction in the assessment of the state of contemporary international relations to date has reached the level of a fundamentally different assessment of the fundamental terms and extremely narrows the space for political and for a strictly neutral and scientific dialogue between the parties. Another example of the terminological differences is presented in the article "the discussion about the power images in international relations theory" where the author notes a serious linguistic discrepancy between the definition of "strength" of the term traditionally well-established in the Russian and English science (Yudin, 2018: 84-99). At the same time, these differences did not go unnoticed and in the internal Russian politics. For example, some researchers have noted fundamental differences in political discourse between representatives of Russian parliamentary parties and the opposition, but not parliamentary parties. According to the research, opposition political parties and movements in Russia categorically disagree on the assessment of all key aspects of Russian foreign policy - such as military actions in Syria, involvement in the military conflict in Ukraine, etc. At the same time, a single opposite view on foreign policy activity among opposition movements also does not exist. Overall, the images of the "quality" of foreign policy directly related to

1 The specificity of most Russian scientific journals lies in the limited number of articles (and translations) in English. The absolute majority of articles are presented only in Russian. Thus, the article quoted in English in the case of the English-language version is officially available. Russianlanguage articles without any English translation are quoted in the author's translation. 
political preferences and conditionally divided into the "liberal," "nationalist" and "socialist" view (Ponomarev, Mailis, 2018: 108-123).

However, a critical view along with a categorical request for a change in the global system of international relations is not totally dominant in the Russian scientific discourse. Thus, in certain cases, it is expressed well-founded fear that the request for a radical modernization of the world political system should include the experience of all previous systems, and not only comply with the discontented parties or countries. At the same time, the requirements for upholding its own sovereignty and a set of conditionally understood national-cultural traditions are presented to the authors as a natural consequence of the increasingly pronounced complication of world politics (Gadjiev, 2018: 81-89).

Another large volume of the articles in leading Russian scientific journals devoted to various aspects of the current relations between Russia and many European countries and European union and another European subnational structures. At the same time, it should be noted that very often in these articles are the European countries in the form of the «Significant Other» (according to the H. S. Sulliwan theory), and rarely focus on specific mutual relations between Russia and one of the European countries. In the article, named as "Defence cooperation models at the northern and on the eastern flanks of the EU (Norden and Visegrad group experience)" author examines the general characteristics of the development of defense initiatives by sub-regional communities such as the Visegrad Group (V-4) and the Nordic Defense Community (NORDEFCO). He also paid attention to the process of interconnection between European and Euro-Atlantic integration, on the one hand, and sub-regional cooperation formats, on the other. He is noted that the sub-regional defense projects and programs are not able to compete with the EU and NATO projects and are currently the most in like «in addition» to it. According to the author, in the current context of increased global uncertainty and growing security challenges, such projects are «little» regionalization have high chances of success (Nadtochey, 2018: 9-40).

As noted earlier, in the Russian foreign policy studies are not very popular "key studies," dedicated to international relations of Russia with the selected countries, and specific aspects of the political development of the chosen country. Especially interesting are the exceptions to this principle, one of which is devoted to the study of a complex system of conflict relations between Poland and the European Union's current leaderboard (Klemeshev, Vorozheina, 2018: 17-28). The authors focus only on the foreign policy aspects of the conflict between Warsaw and Brussels, while practically not analyzed on the complex set of domestic political, economic and other reasons that influenced the development of this conflict. In conclusion, the authors propose four main scenarios with which this confrontation can be finished - two "positive" and two "negative." The «positive» scenarios Poland achieves the status of a regional leader in Central and Eastern Europe in the system of a reformed European Union. Differences in the scenarios consisting in the possible ways to institutionalize this process - through the Visegrad Group, or as part of the Polish foreign policy doctrine written by E. Giedroyc and E. Meroshevski. In a negative scenario, according to Russian authors, Poland remain in the status of the eternal opponent of Brussels, but with no real abilities to influence the direction of the main European Union policies, or be forced to radically change its own foreign policy after the election would be victorious for the Polish liberal opposition.

Another important trend in Russian foreign policy research is clearly seen the trend in the study of various aspects of Russian-Chinese relations. In some cases, such studies seem frankly complementary to China and its foreign policy and practically do not contain any crit- 
icism (Lecsiutina, 2018: 60-72). For example, in the Russian scientific journal "Comparative Politics Russia" were published the detailed results of a large conference specifically devoted to the consequences of the 19th Congress of the $\mathrm{CCP}^{2}$ and the analysis of policy statements made by the leaderboard of the $\mathrm{PRC}^{3}$ (Article E, 2018: 140-159). The authors thoroughly discuss the transformation of political power in the PRC, analyze the names of the new members of the Political Bureau in the Central Committee of CCP, evaluate the new goals of socio-economic development and weigh the chances of different modernization models and its effectiveness. Another analysis is devoted to the transformation of national interests and foreign policy priorities of the PRC, relations between the PRC and the USA, the PRC and Russia, as well as the PRC and East Asian countries. Also published is a program interview of the Russian ambassador to the PRC, Andrei Denisov, who notes that "the current RussianChinese relations is the best in the all our history" (Interaffairs, 2018).

Another analysis is devoted to various aspects of China's military strategy, and the assumption is that China is increasing the volume of its own nuclear capabilities in order to achieve complete «nuclear» equality with the United States, and in the future - even limit any serious opportunities for US actions in the Southeast Asia region (Kashin, 2018: 72-84).

Summarizing the results of this analysis, it can be noted that the main trend in the research of Russian scientific publications analyzing foreign policy is global and local crises, both domestic and foreign policy. At the same time, such studies often represented excessively global and cover an extremely broad and general theoretical aspects of international relations. The second trend in the Russian international policy research is the «turn to the East». According to this internal political trend the main focus of Russian scientific interest has clearly shifted towards PRC. And finally, it is worth noting a clear drop out of the scientific trend of the system of Russian-Ukrainian relations. Perhaps the reason for this phenomenon consisting in the excessive media aggression both sides of the conflict and the background of information warfare in the Russian and Ukrainian media. This situation has led to a reduction of scientific contacts between Russian and Ukrainian scientists and current situation is still not so friendly process of making balanced and unbiased analysis of the current status of the relations between Russia and Ukraine.

Alexandr MACUHIN

Kishinev

\section{REFERENCES}

Yudin N. (2018) Faces of power: debate in international relation theory. A wrong turn? „International Trends", Vol. 16, No. 3 (54).

Tsigankov P., Trenin D., Lomanov A. et al. (2018), Current and faster moment, „Russia in the Global Affairs", Vol. 4.

Lukin P., Oznobischev S. (2018), Russia in the World of the 21 $1^{\text {st }}$ Century: Accomplishments and Hopes, „Polis. Political Studies”, Vol. 6.

Ponomarev N., Mailis A. (2018) Russia's foreign policy in the evaluation of the leaders of the nonsystem opposition: a comparative analysis, „Comparative Politics Russia”, Vol. 9 (4).

\footnotetext{
${ }^{2}$ Officially named as Chinese Communist Party.
}

3 Officially named as People's Republic of China. 
Gadjiev K., Some advocacy points to Westphalian principles, „International Affairs (russian)”, Vol. 11.

Nadtochey Y. (2018), Defense cooperation models at the northern and on the eastern flanks of the EU (Norden and Visegrad group experience), „Comparative Politics Russia”, Vol. 9 (2).

Klemeshev A., Vorozheina Y. (2018) National-Conservative "Turn” of Poland in Geopolitical Context, „Polis. Political Studies”, Vol. 5.

Article E. (2018), 19 ${ }^{\text {Th }}$ National congress of the Communist party of China: internal and external effects and prospects of China's reforms, "Comparative Politics Russia", Vol. 9 (2).

The current Russian-Chinese relations is the best in all our history (In Rus. Нынешние российские - китайские отношения - лучшие за всю историю) (2018), “The International Affairs (Russian)", https://interaffairs.ru/news/show/21713.

Kashin V. (2018), China's military strategy in present (In Rus. Военная стратегия Китая на современном этапе), Vol. 6.

Lecsiutina Y. (2018), China as a responsible world power, "The International Affairs (Russian)", Vol. 16. 